\title{
HEALTHTECH STARTUPS INTERNAL CONTROL TO INCREASE COMPETITIVE ADVANTAGE IN THE NEW NORMAL ERA
}

\author{
Aulia Nurazizah*1), Novita ${ }^{2)}$ \\ Universitas Trilogi, Jakarta, Indonesia \\ Nurazizah.aulia1998@gmail.com ${ }^{1)}$,novita_1210@trilogi.ac.id ${ }^{2}$
}

\begin{abstract}
This research aims to prove the positive influence of the implementation of COSO internal control on increasing competitive advantage in health startups in the New Normal Era. This research is a quantitative study using primary data in the form of questionnaires and secondary data in the form of online interviews. The unit of research is a health start-up, namely the Halodoc Application. The population in this study were users of the Halodoc Application and then the research sample was taken using nonprobability sampling techniques. So that the number of samples processed for analysis is 100 samples. The data analysis technique used descriptive analysis and verification methods. The results showed that the implementation of COSO internal control implemented by the Halodoc Application had a positive effect in increasing competitive advantage.
\end{abstract}

Keywords: Internal Control COSO; Competitive Advantage; Healthtech Startups; New Normal Era

*Corresponding author

Email: Nurazizah.aulia1998@gmail.com

DOI: https://doi.org/10.33369/j.akuntansi.11.2.105-122

\section{INTRODUCTION}

Competitive advantage is the ability to get greater attention compared to other parties who manage similar activities (Kabai, 2016). The very rapid emergence of startup companies makes startup companies also have to think about competitive advantages both in terms of innovation and services provided to consumers, including in choosing the right market segmentation. One of the startup business fields that grew rapidly during the Covid-19 epidemic was startups engaged in health services. The habit of the community when they are sick is by going to the hospital or doctor directly, so during the Covid-19 pandemic in 2020 it becomes limited, this is done to anticipate the spread of the plague. With these conditions, Halodoc as a health service startup has become the community's choice for treatment and health consultations, and this encourages Halodoc to continue to improve innovation and service quality as a competitive advantage in gaining market share with other health startups emerging. Based on data quoted from Rahma (2020) Halodoc made new innovations in the momentum of the COVID-19 (Coronavirus Disease) pandemic as explained by Felicia Kawilarang, Vice President Marketing, that the main strategy being carried out to increase Halodoc's competitive advantage with other health startups was to present a COVID-19 feature with the name AI chatbot. This feature collaborates with Mitra Keluarga Hospital and COVID-19 rapid test. This feature is one of the factors that can increase transactions up to 10 times and an increase of 2 million downloaders within one month after being launched during the pandemic. (Rahma, 2020). The next strategy carried out by Halodoc as an effort to increase its competitive advantage is the Ministry of Health of the Republic of Indonesia in terms of drive-thru vaccinations in Blok C3 Komplek Kemayoran, Central Jakarta (TOW), 2021). The innovation and service improvements that have been provided by Halodoc have made Halodoc successful and survive in an environment of fierce business competition and have shown that Halodoc is able to increase its competitive advantage, with the success of Halodoc being ranked the 150 most innovative digital health in 2020 (Fatta, 2007). 
In addition to the innovation and improvement in service quality presented by Halodoc in attracting the attention of consumers and expanding market share and making achievements in the 150 most innovative digital health in 2020, increasing Halodoc's competitive advantage can also be achieved by implementing a good internal control system in carrying out operational activities, reporting, as well as compliance at all levels starting from the entity level to the executive level. Danke (2012) said that internal control is currently increasingly needed by companies that want to carry out their activities effectively and efficiently so that the company's goals of increasing competitive advantage can be achieved. The increase in competitive advantage can be more easily achieved by implementing internal controls based on the COSO framework. Internal control The COSO framework is a process carried out by the board of directors, management and employees to provide adequate security to meet the objectives of operational effectiveness and efficiency, reliability of information and compliance with applicable rules and regulations (COSO), 2013). There are five components in the COSO internal control framework, including the Control Environment covering the company's code of ethics, commitment to competence and performance measurement, incentives and rewards to encourage performance accountability. Risk assessment is a tool in risk mitigation so that companies can make plans that will be implemented to maintain their business, the company's risk assessment process must be carefully considered starting from identifying company risks, managing risks, seeing potential fraud that may occur to monitoring changes that arise from internal and external external ((COSO), 2013).

Company-made plans can work smoothly when supported by activity control, Arens (2015) explain the company in carrying out its activities to be more effective if it implements internal controls such as segregation of duties, appropriate authorization, complete documents and records, physical control over assets and records and performs independent performance checks Activity control is one of management's efforts to ensure that all actions to mitigate risks have been taken. After the controls are set up, management will inform all parties involved to minimize any miscommunication that might occur. The implementation of internal controls also needs to be monitored regularly and continuously, this process is important as a form of corporate evaluation if there are controls that are not suitable or not as expected. Riyanto (2018) said the internal environment needs to be analyzed to determine the strengths and weaknesses that exist within the company. The internal environment consists of structure, culture and resources. The structure is reflected in the form of an organizational chart which aims to describe how the company distributes and delegates authority and work flows and communication flows. Culture is a pattern of beliefs, expectations, and values shared by organizational members, whereas organizational norms specifically generate and define acceptable behavior for members from top management to operative employees. Furthermore, resources are defined as assets that are used by the company in carrying out operational activities that can provide benefits to the company in the future. These assets may include human expertise and capabilities, financial capabilities, factory facilities in functional areas, as well as information technology facilities that support company activities in achieving goals and increasing the company's competitive advantage. The results of his research explain that the company's ability to innovate is a very vital element in increasing competitive advantage because innovation can meet increasingly varied customer needs so that customers are interested in making purchases at the company.

With the digital age supporting the rapid development of startups in Indonesia, Startup is an institution created to create new and innovative products or services under conditions of high uncertainty (Ries, 2011), and in carrying out operational activities, startups including health startups like Halodoc also need the implementation of proper internal controls. This 
research is important because Halodoc is one of the health startups that has experienced an increase in users during the COVID-19 pandemic with the government's appeal not to come to the hospital if it is not in an urgent situation, so if Halodoc as a research unit in the field of health services based on online applications cannot implementing internal control based on the COSO framework properly in carrying out its operational activities so that in the future it can become an obstacle in increasing competitive advantage. One example of internal control implemented by Halodoc is implementing a code of ethics and commitment to the competence of doctors who provide consultations to consumers, so that consumers have no doubt that online medical treatment and consultations are no different from offline (face to face with the doctor).

Anthony et al., (2012) explaining agency theory defines an agency relationship arises when one or more people (principal) employ other people (agents) to provide a service, then delegate decision-making authority to the agent. With the agency relationship between the principal and the agent, an organization in this case the company must have effective internal controls so that the company's objectives in terms of operations, financial reporting and compliance can be achieved. The Halodoc platform acts as an agent and a doctor as a principal. The agency theory in this study also explains the doctor's belief in the credibility of the Halodoc application as a forum for doctors to provide health services online. The credibility of a platform can be supported by designing and implementing appropriate controls to achieve increased competitive advantage. The increasing demand for health startups creates competition among health startups, so that health startups must have a competitive advantage. Competitive advantage is the ability to get greater attention compared to other parties who manage similar activities. Service quality is a fundamental strategy for companies to succeed and survive in an environment of intense business competition (Kadarningsih, 2013), because with good service quality is expected to increase consumer loyalty. Competitive advantage can also be achieved by product differentiation, a differentiation strategy that makes companies try to be unique in their industry on various dimensions that are generally valued by consumers (Porter, 2008). Aside from differentiation, corporate image is also something that consumers consider when choosing a healthcare startup. The company's good image can be reflected in management's ability to serve consumers and in the company's own trustworthiness. Management's ability to serve consumers can be the first step in creating quality relationships with consumers. Good relationships with consumers can be established through smooth communication and mutually beneficial collaboration.

Martias (2018) argues that the control environment consists of measures, policies and procedures that reflect the general attitude of top management, directors and commissioners, and owners of a company towards control and its importance to the business unit. In another theory, Tadeko (2017) says that the control environment is the dominant element that influences other control elements. A poor control environment leads to the failure of other components to work. Shoimah (2015) has a different opinion, namely internal and external factors, where external factors influencing employee performance are the environment, which includes organizational guidelines, leadership, actions by colleagues, supervision, wage systems and the environment.

Risk assessment is an assessment activity that addresses potential threats to the achievement of government agencies' goals. The risk concept is related to the uncertainty (Tadeko, 2017). This component is an indicator that most influences the internal control variable, that is, the risk assessment. This requires management's ability to assess the risks that arise in each work unit (Taradipa, 2017). In this research, Martias (2018) argues that control policies and procedures are in place to ensure that the measures necessary to overcome risks are actually implemented. The control activities include various controls that 
are detective and preventive in nature (Tadeko, 2017). Employees who have implemented and adhered to the regulations issued by management will harmonize the employee's performance (Maharani et al., 2015).

In the research Tadeko (2017) it is explained that information and communication is a process of collecting and transmitting or exchanging information that is necessary for the implementation, management and control of agency activities. Maharani's (2015) opinion states that information and communication have a good influence on improving employee performance, since information and communication within a company are part of the goals of adequate internal control. After these processes have been carried out, internal controls must also be monitored regularly. However, in his research Martias (2018) explains that monitoring is an internal control activity performed on an ongoing or regular basis by management to determine if the control is working as expected. With structured internal control, it will produce good performance including a competitive advantage strategy as said by Istanto (2010) a competitive advantage strategy supported (conveyed) by a positioning advantage strategy will further improve performance.

Previous research that examined the effect of internal control on employee performance in the medical service division stated that internal control had a significant effect on employee performance in the medical division at Jember Hospital (Maharani et al., 2015). Meanwhile, in other studies that examine the effect of the internal government control system on service quality, it is stated that the internal control system has a significant effect on service quality (Tadeko, 2017). The difference in this study from previous studies lies in the variables tested, where previous studies used service quality as the dependent variable. Apart from the variables tested, the research unit is also one of the differentiators from previous studies, where previous research was conducted on companies that had not implemented an online system, whereas in this study the research unit was an online application-based health service startup. The development of the digital era is the main reason this research was conducted, because in the digital era it has an impact on almost all company business activities. Therefore, startups also need to design and implement their internal controls properly so that business continuity can be maintained, company goals can be achieved, and can increase the company's competitive advantage over competitors. So that the purpose of this study is to see the positive effect of internal control based on the COSO framework on competitive advantage in health startups. This research is expected to contribute to the development of startups, especially health care startups like Halodoc, in order to increase their competitive advantage by implementing internal controls based on the COSO framework appropriately and properly. So, this research hypothesis:

$\mathrm{H}_{1}$ : There is a positive influence between the internal control of the COSO framework and the increase in competitive advantage.

\section{RESEARCH METHODS}

The data were collected using a questionnaire method. The questionnaire was sent to users of the Halodoc application with a sample of 100 respondents based on a sample formula from an unknown population and secondary data from Halodoc youtube in order to obtain valid information from management. Measurement of variables with a rating scale instrument on a scale from 1 to 4 . Respondents are asked to give a value from the statement that agrees with those who disagree. The validity and reliability of the questionnaire tool were measured in order to obtain valid and reliable data Akuon \& Ridwan (2013) said that if the population in the study is unknown, the sample in the study can use the sample measurement formula as follows: 


$$
n=\left(\frac{\frac{z \alpha}{2} x \sigma}{e}\right)^{2}
$$

$$
\text { Information: }
$$

n : Sample size

$\mathrm{Z} \alpha \quad: \mathrm{Z}$ table value $=0.05$

$\sigma \quad:$ The standard deviation of the population

e : error rate

Therefore, the minimum sample that can be drawn in this study is:

$\mathrm{n}=\left(\frac{(1.96)(0.25)}{0.05}\right)^{2}=96.04$

The minimum number of samples for Halodoc users generated from the above calculation is 96.4 , which is rounded up to 100 samples. Methods of data analysis in this study using descriptive analysis and verification. Descriptive analysis is used to explain the research variables for problems related to the extent of the increase in competitive advantage using COSO's internal control framework, and verification analysis is used to test the extent to which the goals achieved will be achieved with the expectation that the Theory is standard. Verification analysis aims to test existing theories and the tests are carried out based on data (Suryana, 2010). The program used as a tool is SmartPLS version 3.3.2, which was specially developed for estimating structural equations. Analyzing the inner model and the outer model can help you determine the relationship between the variables. This test has criteria, if the t-statistic is better than the t-table, it means that the hypothesis is supported or accepted. In this study, the confidence level is $95 \%$ and the alpha is $5 \%$, so the t-table is 1.96 (Ghozali \& Latan, 2015).

\section{RESULTS AND DISCUSSION}

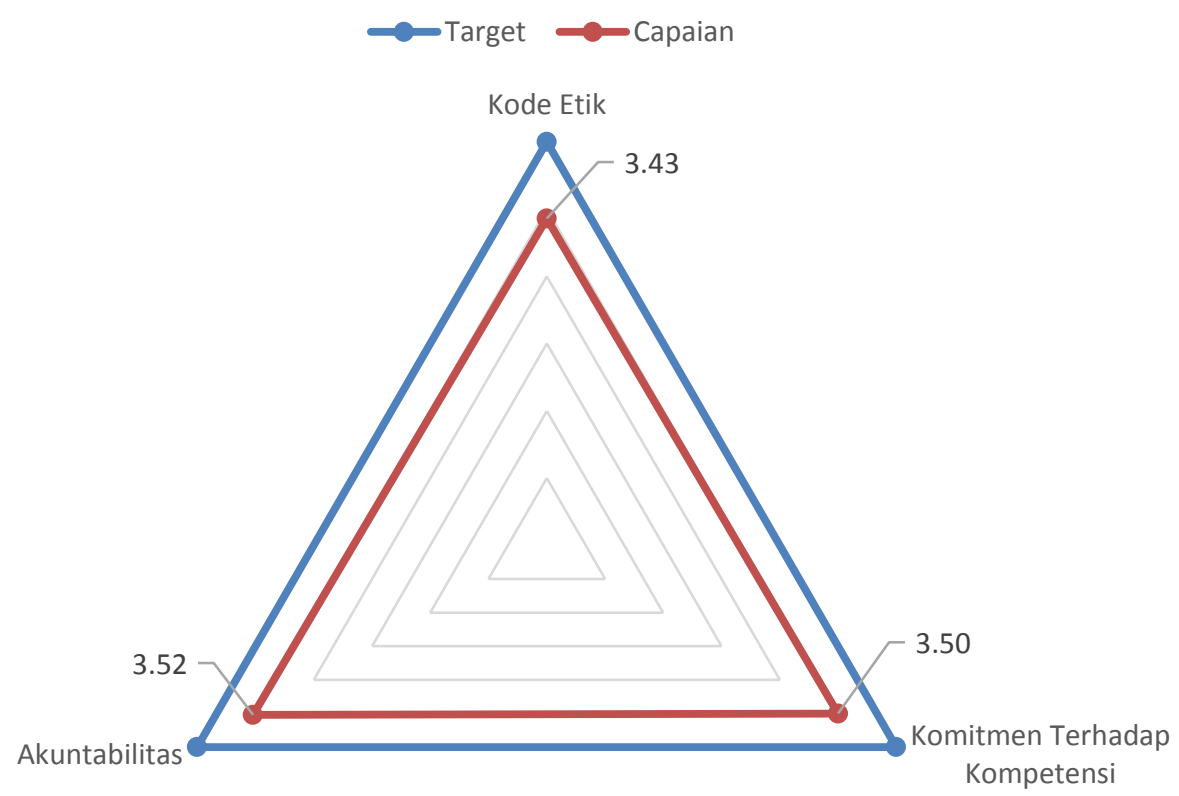

Figure 1. Results of descriptive analysis of suboperative control environment variable

Source: processed questionnaire, SmartPLS (2020) 
Figure 1 shows that the average respondent's answer is in agreement, with a value above 3, which means that the Halodoc application has implemented the control environment components contained in the internal control based on the COSO framework. The control environment is reflected in the existence of a code of ethics, commitment to competence and accountability that belongs to Halodoc. Halodoc's Code of Ethics is designed to make patients feel comfortable and secure in transactions using the Halodoc application so that user increases can be achieved as management desires by maintaining the confidentiality of consumer data. The code of conduct applied by Halodoc also requires doctors to prescribe it by implementing the right medication, patients are comfortable with the advice of using Halodoc.

Doctors in the Halodoc application have skills appropriate to their areas of expertise so that any disease a patient complains about is treated by the right doctor so that the diagnosis of the disease given to the patient is correct to avoid misbehavior. This is supported According to a statement by Halodoc CEO Jonathan Sidhata on the Najwa Shihab Youtube channel, the doctors available in the Halodoc application are more than 20,000 competent doctors. After the patient is properly diagnosed, the doctor will prescribe the appropriate drug. Halodoc also always gives recommendations for the closest pharmacy from the patient's location for the drug purchase process. According to Jonathan Halodoc, he has worked with more than 1,000 pharmacies in Indonesia. The accountability of the Halodoc application may be reflected in the high level of public interest in consulting on the Halodoc application. This is because the drugs recommended by doctors match the patient's diagnosis of disease, so the patient's healing time is faster. Therefore, the public has great confidence in transactions made using the Halodoc application.
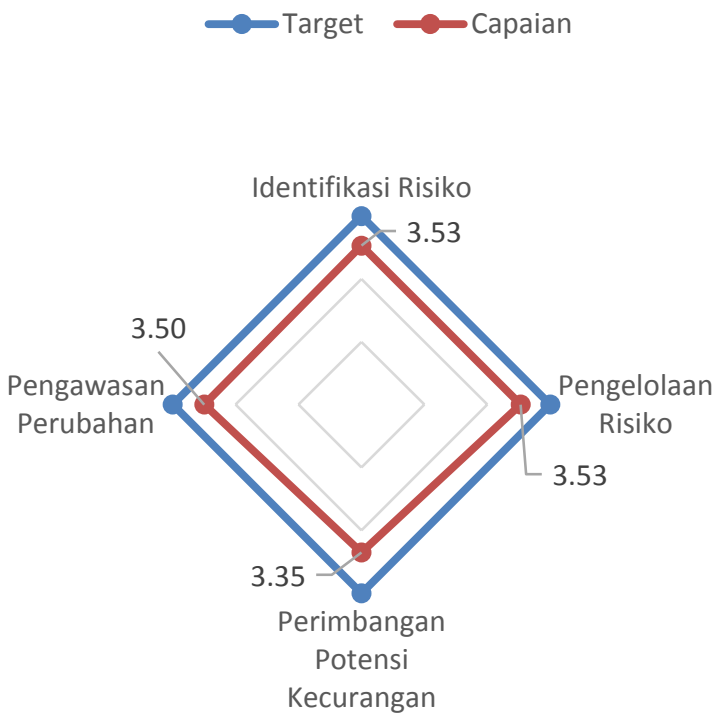

Figure 2. Results of the descriptive analysis of the suboperative risk assessment variable

Source: processed questionnaire, SmartPLS (2020)

Figure 2 shows that the average respondent's answers are consistent. A value above 3 means that the Halodoc application has implemented the risk assessment component contained in the internal control based on the COSO framework. Various factors are taken into account when performing the Halodoc risk assessment, such as: B. the risk identification process, the management of these risks, the consideration of potential cases of fraud and the monitoring of changes. As for risk identification, the Halodoc application has several competitors in its market, so the Halodoc application must continue to innovate in order to 
keep its existence. When consulting the Halodoc application, the patient is given a period of time so that the patient can make good use of the consultation time and explain the patient's complaints in detail so that the doctor can make the correct diagnosis.

Once the risks have been identified, these risks must be properly managed. The risk management carried out by the Halodoc application can be reflected in attractive offers of the Halodoc application such as discount coupons for consultation. While consulting doctors about Halodoc use, they respond to patient complaints so that the consultation process can be effective. After completing the consultation process, the doctor always prescribes medication. The drug delivery process does not require a long time, so patients do not have to wait a long time to receive the drug. The Halodoc application has taken into account the potential for fraud that can arise through the payment process, which can only be performed with the Halodoc application. This is done to minimize the possibility of fraud by doctors. Patients also have the freedom to choose a doctor for consultation. Generally, patients choose a doctor who has a high rating on the doctor's profile. The assessment is given by the patient after the consultation. The doctor's rating reflects the doctor's ability and patient satisfaction with The Doctor. Halodoc application always strives to meet patient needs by following changes caused by external factors such as: B. the Halodoc application which launches the newest feature, which is Check for COVID-19 during a COVID-19 pandemic. Jonathan Sidharta said this feature is useful in preventing the spread of COVID-19 as Halodoc provides facilities to schedule appointments for COVID-19 tests in hospitals, laboratories and clinics. With the pandemic, the government is asking all people to do PSBB and stay home when there is no urgent need. In the pandemic, therefore, people use the Halodoc application more often than in the hospital to consult about health.

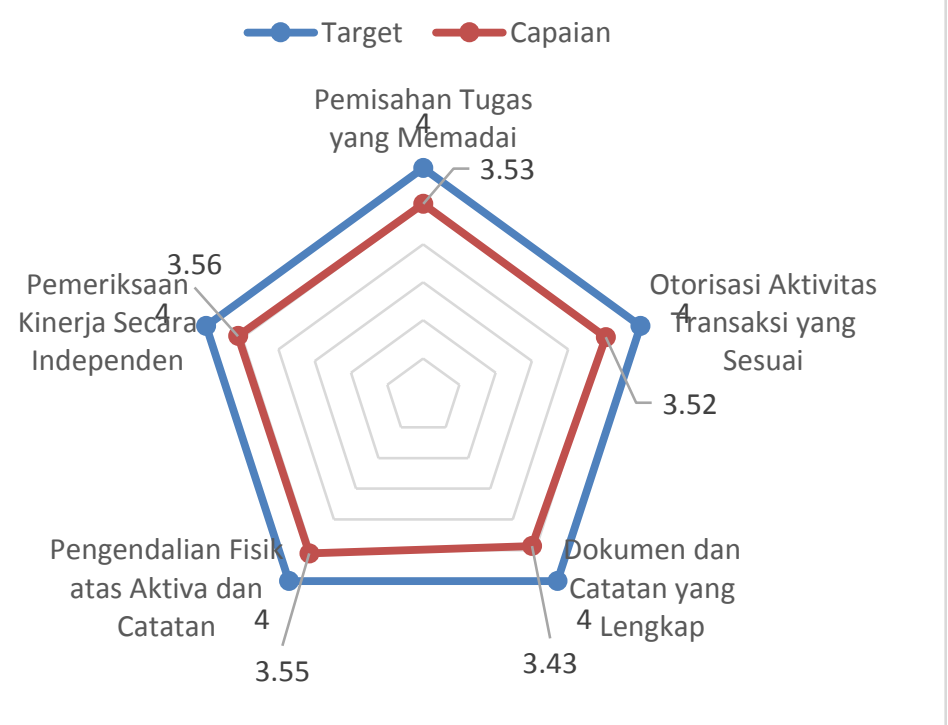

Figure 3. Results of the descriptive analysis of the control activities variable Source: processed questionnaire, SmartPLS (2020)

Figure 3 explains that the average respondent's answers are in agreement with a value above 3, which means that the Halodoc application has implemented the internal control component for control activities based on the COSO framework. Control activities can be carried out through segregation of duties, appropriate authorization, appropriate documents and records, physical control of assets and records, and independent performance reviews. The Halodoc application has performed a segregation of duties by classifying each doctor according to their specialty and giving patients the choice of whether or not to purchase drugs from the application. This is done to simplify transactions with the Halodoc application. 
Patients can choose doctors based on their needs as long as the doctor is online. This is done by Halodoc so that the doctor can react quickly to patients in the consultation process so that an effective consultation takes place. According to Jonathan, this is one of the goals of the Halodoc application, which is to provide health services that are simpler and that can be accessed anywhere, anytime. For advisory payments, the Halodoc application also offers options. Patients can use bank transfers or e-wallets provided by the Halodoc application. This is a form of authorization carried out by the Halodoc application. In the initial phase of registration, patients are required to enter their full personal information. This is intended for the needs of the Halodoc application database. After a consultation, the doctor always provides notes on the patient's disease diagnosis and medication prescriptions as documents that are given to the patient.

Doctors available in the Halodoc application also have a valid STR, so the quality and competence of the doctors cannot be in doubt. When conducting consultations on the Halodoc application, the doctor always provides a summary of the conversation during the consultation as a file that the patient can save. The drug sent to the patient also corresponds to the order. Therefore, patients are satisfied with the staff who receive the Halodoc application. An independent performance check is also required in the control activity component by sending notifications of every transaction carried out, e.g. B. Notification of successful payments, notification of drug dispensing and notification of received drugs. In addition, the Halodoc application sends information to patients about attractive offers from the Halodoc application.

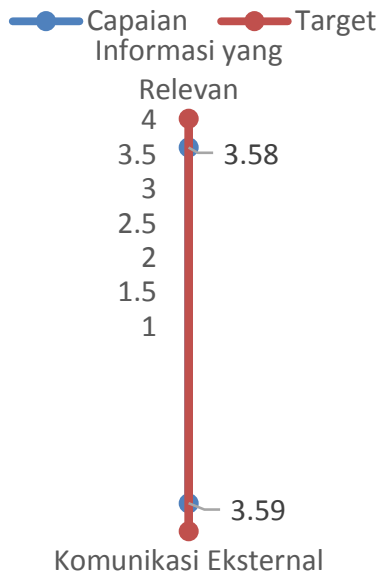

Figure 4. Results of descriptive analysis of suboperative information and communication variable

Source: processed questionnaire, SmartPLS (2020)

Figure 4 shows that the average respondent's answer is the same. A value above 3 means that the Halodoc application has implemented the information and communication components contained in the internal control based on the COSO framework. In this component, the information communicated to the parties concerned must be relevant information. The relevant information may be reflected in the consultation price, which is clearly stated. Jonathan stated that this was done to remove society's stigma about the expensive price of the doctor's consultation. In addition to relevant information, external communication must be established so that effective communication takes place between management and users. External communication can be reflected in the chat function between doctors and patients, and the presence of customer service can be a bridge for communication between users and management. 


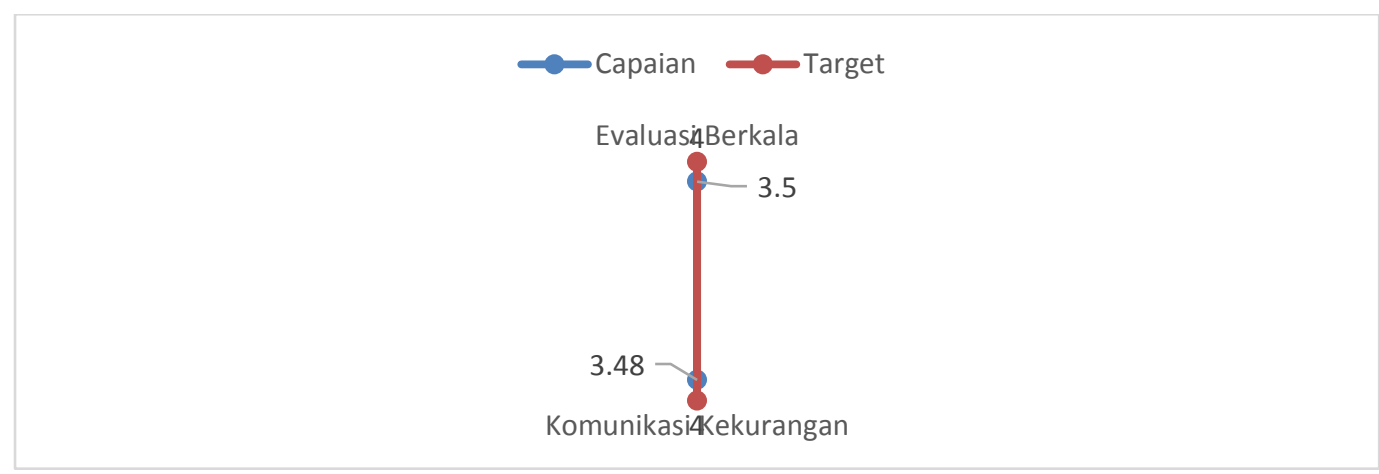

Figure 5. Results of descriptive analysis of suboperative monitoring variable Source: processed questionnaire, SmartPLS (2020)

Figure 5 shows that the Halodoc application has implemented a monitoring component included in the internal COSO control, for which the average respondent gives a value above 3.0. In this component, the Halodoc application has carried out regular assessments and reports on the deficiencies of the designed internal control. Evaluations are carried out regularly with maintenance work carried out by the Halodoc application to improve the appearance of the application and make it easier to access. Communication about the lack of applied controls can be done by giving the patient the opportunity to provide criticism and suggestions about the patient's experience in transactions with the Halodoc application.

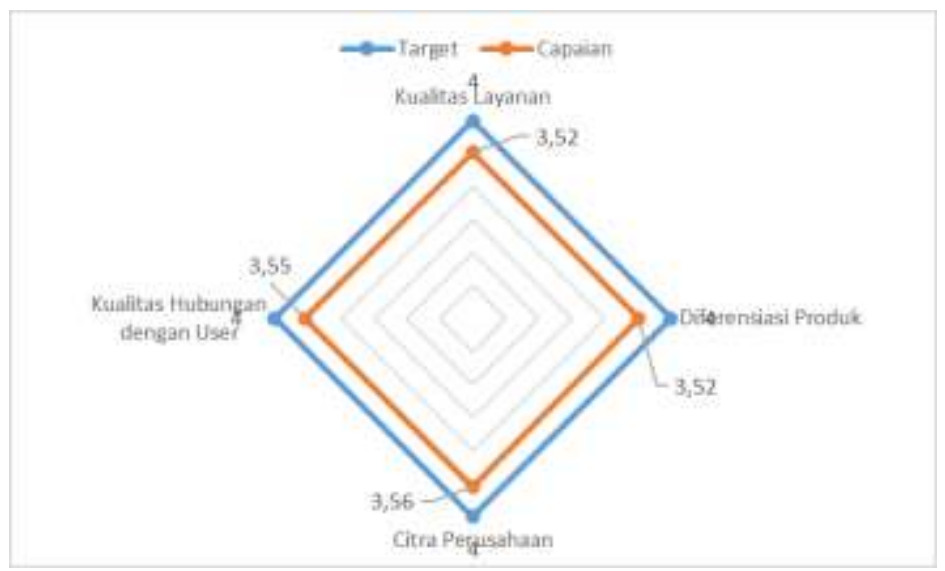

Figure 6. Results of descriptive analysis of competitive advantage variables Source: processed questionnaire, SmartPLS (2020)

As can be seen from Figure 6, the competitive advantage of the Halodoc application can be achieved by improving the quality of service and improving the quality of the relationship with the user. The Halodoc application always improves the quality of service by accepting criticism and suggestions from patients so that the quality of the service meets the expectations of the patients. In addition, the Halodoc application continues to innovate by developing functions according to patient needs taking into account the many competitors in the market, so that the Halodoc application can keep its existence with new innovations. In order to continue to exist, the Halodoc application also expands the cooperation with several hospitals and health services in Indonesia, which improves the image of the Halodoc company in the public eye. Halodoc also takes into account the relationship with the user so that a mutually beneficial cooperation can still be well established. This is reflected in Jonathan's expression: "We welcome honest comments from people who are being helped. Because we now serve not only quickly and conveniently, but also economically. And this drug service is also time efficient and inexpensive, the difference can be $50 \%$, "he said. 
The quality of service of the Halodoc application includes complete and simple features so that patients can find their needs. The Halodoc application provides clinicians who are reliable in handling patient complaints to increase patient confidence in transactions using the Halodoc application. The Halodoc application also provides accurate time estimates, e.g. B. Estimating drug delivery so that much patient time is not wasted. In addition, due to regular updates, there is rarely any interference with the use of Halodoc, so patients are comfortable with the use of Halodoc. During the consultation with the doctor, the management reacts very openly to criticism and suggestions from patients, which leads to two-way communication between the patient and the Halodoc application. The Halodoc application guarantees the confidentiality of patient data, so that there is a feeling of security in transactions.

To increase the competitive advantage, the Halodoc application must be differentiated in the face of the presence of competitors. This distinction can be seen in the appearance of the Halodoc application, which is simple and easy to understand and is equipped with attractive animations to make it more comfortable for patients to use, and the functions of the Halodoc application are more diverse. Compared to competing applications, this is supported by the presence of a new feature in 2020, namely the COVID-19 test. Halodoc offers the first ride through the COVID-19 test facility in Indonesia. In addition to differentiation, a corporate image must be created in order to increase the positive value of the company in the eyes of the community. This image can be built with management's ability to deliver services to patients. With positive value in the eyes of the community, people will choose the Halodoc application in online health services and recommend it to their relatives and the local area. The quality of relationships with users is important to be improved by smooth communication. Communicating with the Halodoc application is to provide patients with good communication services for both criticism and suggestions and the latest information about Halodoc.

\section{Analysis of the review of the outer model}

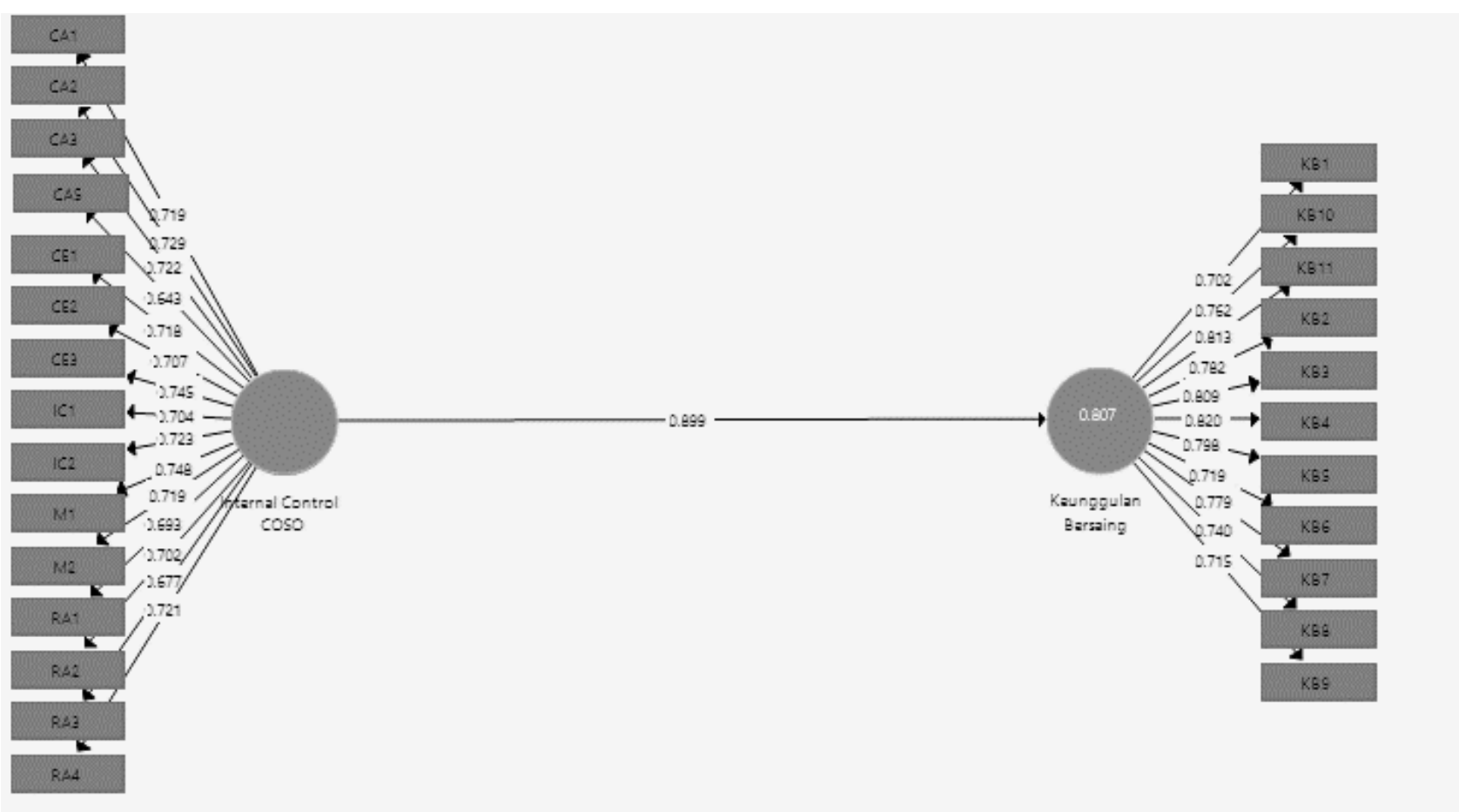

Figure 7. Validity test results using the standardized loading factor 
Based on Figure 7, it can be seen that the validity test results can be seen through convergent validity test in the load factor value. Out of a total of 26 indicators with a stress factor, a correlation value is above 0.70. However, there is a stress level above 0.05-0.60 that is still acceptable. It can be interpreted that a cautious indicator has a pretty good load factor value. Initially, the external exposure value did not meet the convergent validity, since there were still several indicators whose external exposure value was still below 0.70 . However, it can be seen that the majority of the indicators have an external stress value greater than 0.70 for each variable. Apart from CA4, it shows that the variable indicator has an external stress value greater than 0.70 , which means that it has a high level of validity so that it can meet the convergent validity criteria. In the meantime, indicators with lower external exposure values are eliminated or removed from the model.

Table 1. Outer Loading after elimination

\begin{tabular}{|c|c|c|}
\hline Indicators & Internal Control $(\mathrm{X})$ & Competitive Advantage (Y) \\
\hline CE1 & $\sqrt{ }$ & \\
\hline CE2 & $\sqrt{ }$ & \\
\hline CE3 & $\sqrt{ }$ & \\
\hline RA1 & $\sqrt{ }$ & \\
\hline RA2 & $\sqrt{ }$ & \\
\hline RA3 & $\sqrt{ }$ & \\
\hline RA4 & $\sqrt{ }$ & \\
\hline CA1 & $\sqrt{ }$ & \\
\hline CA2 & $\sqrt{ }$ & \\
\hline CA3 & $\sqrt{ }$ & \\
\hline CA5 & $\sqrt{ }$ & \\
\hline $\mathrm{IC} 1$ & $\sqrt{ }$ & \\
\hline $\mathrm{IC} 2$ & $\sqrt{ }$ & \\
\hline M1 & $\sqrt{ }$ & \\
\hline M2 & $\sqrt{ }$ & \\
\hline KB1 & & $\sqrt{ }$ \\
\hline KB2 & & $\sqrt{ }$ \\
\hline KB3 & & $\sqrt{ }$ \\
\hline KB4 & & $\sqrt{ }$ \\
\hline KB5 & & $\sqrt{ }$ \\
\hline KB6 & & $\sqrt{ }$ \\
\hline KB7 & & $\sqrt{ }$ \\
\hline KB8 & & $\sqrt{ }$ \\
\hline KB9 & & $\sqrt{ }$ \\
\hline KB10 & & $\sqrt{ }$ \\
\hline KB11 & & $\sqrt{ }$ \\
\hline
\end{tabular}

These Table shows the results of the analysis that the discriminant validity test between the internal COSO control and the resulting competitive advantage is validated. From the picture above it can be seen that the values from the results of the discriminant validity test are 0.735 and 0.768 , which means that a value of $>0.70$ is produced for all variables used.

Table 2. Results of the discriminant validity analysis

\begin{tabular}{ccc}
\hline & Internal Control & Competitive Advantage \\
\hline Internal Control & 0.735 & \\
\hline Competitive Advantage & 0.869 & 0.768 \\
\hline \multicolumn{2}{c}{ Source: processed questionnaire, SmartPLS (2020) }
\end{tabular}


Another way to measure the degree of validity between constructs is to look at the AVE (Average Variance Extracted), which is listed in Table 3 below. When the resulting AVE is greater than 0.50 . Table 3 shows the output results that indicate an AVE value greater than 0.5 , which means that there is no problem with the variable being tested.

Table 3. Results of the construct reliability and validity analysis

\begin{tabular}{crrrr}
\hline & Cronbach's Alpha & rho_A & Composite Reliability & AVE \\
\hline Internal Control & 0.915 & 0.917 & 0.928 & 0.541 \\
\hline Competitive Advantage & 0.930 & 0.935 & 0.940 & 0.590 \\
\hline Source: processed questionnaire, SmartPLS (2020) & & &
\end{tabular}

Internal Control COSO has an AVE of 0.541 and a competitive advantage of 0.590. Using the two methods above, it can be concluded that all constructs have a fairly high or valid degree of validity discrimination because they met the criteria.

\section{Reliability Test}

a) Cronbach's Alpha

Table 3 explains that the reliability test for all constructs, namely COSO Internal Control with a value of 0.915 and a competitive advantage of 0.930 , gave a Cronbach alpha value above 0.70 . It can be interpreted that the test results of all variables are trustworthy because they have a high degree of reliability.

b) Composite Reliability

Table 3 explains the composite reliability value that is useful in measuring indicators for all constructs in this study to determine whether or not the indicators used are reliable. Then the resulting value is above 0.70 . It can be interpreted that all constructs used have a high reliability and no reliability problems are found in the model formed, so that it can be described as good. Because the result is 0.928 in COSO Internal Control and 0.940 in Competitive Advantage.

\section{Analysis of the review of the inner model}

The path coefficient is the value of the path coefficient. If the resulting value between the latent construct and the endogenous construct is positive, there is a positive relationship and vice versa. It can be seen in Table below, which shows that the COSO construct for the internal control has a positive value of 0.869 compared to the endogenous construct (competitive advantage). It can be concluded from this that latent constructs have a positive effect on endogenous constructs.

Table 4. Path coefficient analysis results

\begin{tabular}{cr}
\hline Internal Control & Competitive Advantage \\
\hline Competitive Advantage & 0.869 \\
\hline Source: processed questionnaire, SmartPLS (2020)
\end{tabular}

The value of $\mathrm{R}$ Square is the coefficient of determination in endogenous constructs. It can be seen in Table 5, which shows the value of R Square (R2) for the endogenous construct (Competitive Advantage Variable) of 0.807. This shows that the influence of the variable COSO Internal Control on competitive advantage is $80.7 \%$ and the remaining $19.3 \%$ is influenced by other variables outside of this research model. Also, if it has a value of 0.807 , it can have a strong and valid relationship because it has an R-squared value greater than 0.67 .

Table 5. R-Square $\left(\mathbf{R}^{2}\right)$ analysis result 


\begin{tabular}{cc}
\hline \multicolumn{2}{c}{ R-Square $\left(\mathrm{R}^{2}\right)$} \\
\hline Competitive Advantage & 0.807 \\
\hline Source: processed questionnaire, SmartPLS (2020)
\end{tabular}

The $\mathrm{Q}^{2}$ value is known to meet the criteria because the resulting value is 0.429 , which means that it is large. From this it can be concluded that the variable COSO Internal Control has a large value which is important for the variable Competitive Advantage.

Table 6. Predictive Relevance (Q Square) analysis result

\begin{tabular}{cccc}
\hline & SSO & SSE & $\mathrm{Q}^{2}(=1-\mathrm{SSE} / \mathrm{SSO})$ \\
\hline Internal Control & 1100.000 & 1100.000 & \\
\hline Competitive Advantage & 1100.000 & 628.542 & 0.429 \\
\hline \multicolumn{5}{c}{ Source: processed questionnaire, SmartPLS (2020) }
\end{tabular}

\section{Hypothesis Test}

In Table 7 it can be seen that the t-statistical value is 34,359 or can be concluded $>1.96$, which means that the hypothesis is accepted or the internal COSO control has an influence on the competitive advantage of the Halodoc application. Then all exogenous variables together have a significant influence on endogenous variables

Table 7. T-Statistics analysis result

\begin{tabular}{cccccc}
\hline & $\begin{array}{c}\text { Original } \\
\text { Sample }\end{array}$ & $\begin{array}{c}\text { Sample } \\
\text { Mean }\end{array}$ & $\begin{array}{c}\text { Standard } \\
\text { Deviation }\end{array}$ & T-Statistics & P Values \\
\hline $\begin{array}{c}\text { Internal Control } \\
\text { - Competitive } \\
\text { Advantage }\end{array}$ & 0.869 & 0.872 & 0.025 & 34.359 & 0.0000 \\
\hline \multicolumn{5}{c}{ Source: processed questionnaire, SmartPLS (2020) } \\
\hline
\end{tabular}

\section{Discussion}

Based on the results of the bootstrapping calculations, the original sample value was 0.869. This figure shows that there is a positive effect of internal control based on the COSO Framework on increasing competitive advantage. The better the implementation of COSO internal control, the better the Halodoc Application's competitive advantage in the New Normal Era. It can be seen that $80.7 \%$ of the competitive advantage of the Halodoc application is influenced by the implementation of COSO Internal Control. The COSO Internal Control with Competitive Advantage, to be precise. This figure shows a greater value when compared to the t-table criterion, namely 1.96 with a p-value of 0.000 , lower than the p-value criterion which should be 0.05 . So it can be concluded that the COSO Internal Control variable has a significant positive effect on Increasing Competitive Advantage.

The results of this study were obtained from the responses of respondents who were consumers of Halodoc. The responses from the management and operational implementers of Halodoc were obtained through interviews from online media due to pandemic conditions during the study period. The similarity of this study with previous research is the internal control variable based on the COSO Framework, while the difference between this study and previous research is that this study sees the effect of internal control in increasing competitive advantage in health service startups where health service startups like Halodoc are one of the startups experiencing an increase in the number of users during the Covid-19 pandemic. And during the Covid-19 pandemic, other health service startups emerged, thus indirectly encouraging Halodoc to strive to increase its competitive advantage by implementing proper and good internal controls. 
These results are in accordance with the research Maharani (2015) which states that internal control has a significant effect on the quality of medical services. In this study, it is stated that the control environment is the engine driving the company and is the foundation of everything placed and employee performance is the executor of the success of achieving company goals, in this study the performance of doctors is one of the foundations for achieving company goals. To achieve this goal, risk assessment is considered to be able to improve performance by minimizing risks in carrying out their duties, with the presence of procedures and policies made by management, which can encourage employees to comply with the established rules and work standards. According to COSO (2013) A good internal control environment is when employees and management carry out their work ethics properly such as ensuring the confidentiality of company data, especially Halodoc patient data and providing the best service for patients so as to provide comfort when patients consult through the Halodoc application. In addition to implementing a code of ethics properly, internal control can be seen from the commitment of all employees to commitment to competence which can be seen from the selection of doctors who are partners for Halodoc so that they can provide good diagnoses to patients and pharmacies that are partners with Halodoc which are trusted pharmacies. and closest to the patient's position during the consultation. On Youtube Shihab (2019) Jonathan Founder of Halodoc explained that from the Halodoc application data it shows that Halodoc provides more than 20,000 doctors who are competent in their fields, both general practitioners and complete specialists, furthermore Halodoc has also collaborated with more than 1,000 pharmacies in Indonesia. When the two things above have been fulfilled, Halodoc can get high trust from consumers and it provides good feedback, namely that consumers believe they will provide recommendations to other potential consumers to consult health through the Halodoc application compared to other health platforms.

Halodoc management represented by Jonathan said that he was pleased with the positive comments given by patients who had transacted on the Halodoc application. Another thing that can be used as a benchmark to see whether or not Halodoc control is good by identifying risks in customer satisfaction. Online health consultations are of course different from offline consultations, where online consultation consumers do not meet face to face with doctors, so as to minimize the risk of consumer dissatisfaction in consulting Halodoc provides a fairly long duration of consultation. In addition, in order for consumers to easily purchase prescription drugs, Halodoc and its pharmacy collaborative network strive to provide the best drug prices compared to market prices. After identifying these risks, Halodoc must be able to manage and overcome these risks, such as providing attractive offers for patients in the form of discounted consultation prices while still paying attention to the competence of doctors who are partners so that they can provide appropriate diagnoses consulted by consumers. This is done as an effort to remove the stigma of society that medical consultations with doctors are very expensive. In the drug delivery process, in addition to providing discounted drug prices, the partner chosen must be the best so that the drugs can be delivered quickly and on time to patients. To manage and overcome the risk of drug delivery, Halodoc collaborates with an online transportation application. Furthermore, in managing and overcoming potential fraud, Halodoc implements payment methods that can only be made in the Halodoc application and consumers are asked to provide an honest assessment to doctors according to the doctor's competence and the consulting services provided. Halodoc also provides a service feature "Check for COVID-19" and this has a positive impact by increasing the number of new downloads for the Halodoc application. According to Jonathan's statement that until 2020 the Halodoc application already has 7 million active users. 
In the theory of internal control based on COSO (2013) It is said that the internal control component which plays an important role is activity control. The form of activity control is manifested by the existence of adequate segregation of duties, Implementation of activity control carried out at Halodoc is to separate patients according to their disease so that they are directly connected with doctors who are competent in their fields to provide proper diagnosis so that drug suggestions recommended by the doctor are in accordance with the disease. suffered by the patient. Jonathan said that the Halodoc application provides a complete range of general practitioners and specialists, from eye specialists to psychologists. In addition to separating tasks as above, the authority that is appropriate for activities and transactions can also be used to improve internal control by connecting patients with the appropriate doctor when the doctor is online and in various payment methods and validated online. In addition, COSO (2013) also mentions that adequate documents and records are one of the factors in terms of increasing internal control because with adequate documents and records such as complete patient data, terms and conditions that must be approved by the patient and a summary of all diagnoses and prescriptions. Medicines given by doctors make Halodoc a good platform because all activities carried out in the application are recorded properly so that all data can be accounted for. The last factor that makes the assessment for activity control is an independent performance check, namely Halodoc definitely sends notifications to patients on the status of payment when it is successful and also always provides information about attractive promos and offers through the Halodoc application.

The results of this study are also in accordance with researche of Tadeko (2017) which states that internal control has a significant effect on service quality, service quality is one of the factors for increasing competitive advantage. This research shows that a good information and communication system can help in making important decisions in service to consumers, including improvements and enhancements to the services provided. Good information and communication on Halodoc can be seen from how management provides relevant information to patients, namely a clear description of the doctor's profile according to the doctor's specialization and competence and communication with external parties where in Halodoc, the patient is like providing a chat feature for patients to doctors when consulting. and to Halodoc customer service. Taradipa (2017) argues that internal control has a significant influence on employee performance, this study explains that monitoring is carried out to find the location of internal control weaknesses in each work unit and provide recommendations for improvements to management to be followed up so that these weaknesses can be made effective. The monitoring that is carried out is sure to have a good influence on internal control because in monitoring there are several things, namely periodic evaluations where the evaluation in question is a re-evaluation of the Halodoc application itself, namely updating the display to make it more accessible to patients and carrying out maintenance to avoid bugs in the application and minimize an error occurs so that the consultation between the patient and the doctor goes well so that it can produce the right diagnosis and increase confidence for the patient which is good feedback for Halodoc so that patients do reconsult when they are sick and surely patients who get satisfied will give good recommendations to colleagues or relatives to consult a doctor through the Halodoc Application.

\section{CONCLUSIONS AND SUGGESTION}

The results of this study also show that the implementation of internal control at Halodoc can meet the company's objectives, both operational, reporting and compliance objectives carried out by all levels from the entity level to the functional (executor) level. Internal control in COSO (2013) explains that an internal control is said to be good if the 
internal control applied can meet the company's objectives consisting of operational, reporting and compliance objectives that are carried out from the entity level to the functional level for the five indicators of internal control, namely: control environment, risk assessment, control activities, information and communication, as well as internal control monitoring. This is proven by the achievements of Halodoc in 2020, namely being included in the ranking of 150 innovative online application-based health services as well as the trust of the ministry of health for health services related to Covid-19. Furthermore, Halodoc's success in implementing internal control properly also resulted in an increase in the number of service users reaching 2 million downloaders in the first month of the pandemic (Rahma, 2020). This shows that good internal control implemented by Halodoc has a positive impact on increasing competitive advantage amid the emergence of other health service applications. 


\section{REFERENCES}

Akuon, \& Ridwan. (2013). Rumus dan Data dalam Aplikasi Statistika. Alfabeta.

Anthony, Robert, N., \& Govindarajan, V. (2012). Management Control System. Salemba Empat.

Arens, A., Elder, R., \& Beasley, M. (2015). Auditing \& Jasa Assurance Pendekatan Terintegrasi. Erlangga.

COSO, C. of S. O. (2013). Internal Control - Integrated Frameowrk: Executive Summary (Coso (ed.)

Danke, Y. (2012). Analisis Perancangan Sistem Informasi Akuntansi pada Siklus Penggajian dalam Rangka Efektivitas Pengendalian Internal (Studi Kasus pada Perusahaan Plastik Injection). Jurnal Bekala Ilmiah Mahasiswa Akuntansi, 1.

Fatta, H. Al. (2007). Analisis \& Perancangan Sistem Informasi Untuk Keunggulan Bersaing Perusahaan \& Organisasi Modern (Andi (ed.); 1st ed.). CV ANDI.

Ghozali, I., \& Latan, H. (2015). Partial Least Squares Konsep, Teknik dan Aplikasi Menggunakan Program SmartPLS 3.0. Badan Penerbit- Undip.

Istanto, Y. (2010). Pengaruh Strategi Keunggulan Bersaing dan Positioning Terhadap Kinerja (Survey Pada Koperasi Serba Usaha di Kabupaten Sleman Yogyakarta). Buletin Ekonomi, 8, 70-170.

Kabai, D. Z. (2016). Pengertian Keunggulan Bersaing , Sumber-Sumber Keunggulan Bersaing. Ekonomiakuntansiid.

Kadarningsih, A. (2013). Keunggulan Bersaing: Faktor-Faktor yang Mempengaruhi Dan Dampaknya pada Kinerja Selling-In. Media Ekonomi \& Teknologi Informasi, 1-18.

Maharani, F., Prita, S., \& W, S. (2015). Pengaruh Pengendalian Internal Terhadap Kinerja Karyawan pada Divisi Pelayanan Medis di Rumah Sakit Jember Klinik. Jurnal Akuntansi Universitas Jember, 13 (2).

Martias, A. (2018). Analisa Pengendalian Internal Terhadap Pelayanan di Terminal Bandar Udara ALKHA. Jurnal Moneter.

Porter, M. (2008). Competitive Advantage (Keunggulan Bersaing): Menciptakan dan Mempertahankan Kinerja Unggul. Kharisma Publisher.

Rahma, E. (2020). Tiga Strategi Halodoc Hadapi Pandemi. Markeeters.

Ries, E. (2011). The LEan Stratup: How Today's Entrepreneurs Use Continuous Innovation to Create Radically Successful Businesses. Crown Business.

Riyanto, S. (2018). Analisis Pengaruh Lingkungan Internal Dan Eksternal Terhadap Keunggulan Bersaing Dan Kinerja Usaha kecil Menengah (Ukm) Di Madiun. Jurnal Manajemen Bisnis Dan Inovasi, 5.

Shihab, N. (2019). Halodoc, Akses Mudah Layanan Kesehatan.

Shoimah, S. (2015). Pengaruh Pengendalian Internal Terhadap Kinerja Karyawan Hotel di Kabupaten Jember. Artikel Ilmiah Mahasiswa.

Suryana. (2010). Metodologi Penelitian Praktis Penelitian Kuantitatif dan Kualitatif. Bandung. Universitas Pendidikan Indonesia. 
HEALTHTECH STARTUPS INTERNAL CONTROL TO INCREASE COMPETITIVE ADVANTAGE IN THE NEW NORMAL ERA

Aulia Nurazizah and Novita

Tadeko, N. (2017). Pengaruh Sistem Pengendalian Intern Pemerintah Terhadap Kualitas Pelayanan Pada Satuan Kerja Perangkat Daerah. E-Jurnal Katalogis, 5 (2), 104-115.

Taradipa, P. (2017). Pengaruh Pengendalian Intern Terhadap Kinerja Karyawan Studi Pada PT Bank Panin Tbk Cabang Kendari. Jurnal Akuntansi, 2 (1), 28-38.

TOW. (2021). Inovasi Vaksinasi Drive Thru Halodoc dan Gojek Diapresiasi Menteri Kesehatan. Trans Online Watch. 